Asian Review of Social Sciences

ISSN: 2249-6319 Vol.7 No.2, 2018, pp. 33-36

(C) The Research Publication, www.trp.org.in

\title{
Future Prospective of Tea-Tourism along with Existing Forest-Tourism in Duars, West Bengal, India
}

\author{
Chandan Datta \\ Senior Research Fellow, Geography Department, Vivekananda College for Women, \\ University of Calcutta, Kolkata, West Bengal, India \\ E-Mail: chandandatta.06@gmail.com
}

\begin{abstract}
Duars has wider potential in the development of tea tourism as a separate industry. Government of West Bengal has focused on Tea Tourism in making it popular among tourist. Duars is land of natural beauty of mountain, dense green forest, waterfall, river, cave which act as a pull factor for tourist attraction. The tea garden adds new dimensions to the beauty of Duars. Tea tourism has been flourished with countries like China, Srilanka and Kenya. It is now spreading in India. Tea tourism which integrates the natural environment of tea garden, tea leaves plucking, tea production, tea packaging and tea labour-culture. It is a new type of tourism which covers different types of tourist entertainment such as sightseeing viewing, roaming in tea garden, having tea in tea stall from different tea factory, watching evening tealabour cultural performance etc.

Keywords: Tea tourism, tea-labour-culture, tea lovers, Duars
\end{abstract}

\section{INTRODUCTION}

For the development of tea-tourism in Duars region, need to produce tea-tourism products and uniqueness which separate other region from it. Tea tourism developments have a dual impact because it will promote regional tea to the tourist which creates a popular market of the tea and economic improvement of the tea labour. For making teatourism strong and more popular, it would integrate with other local culture and natural beauty of Duars. The study of this subject will give valuable information for the decisionmaking of the government for the development of tea industries in other areas both of West Bengal and India. Tea-tourism is another type of tourism of Duars which is being developed along with other existing tourism. (K.C. Kothagoda and S. C. Thusara 2016). Tea lovers are the main tea-tourist in tourism industry. Tea tourism can develop parallel with wine industry (S. Sharmin and K. S. Rahnuma, 2018)

\section{STUDY AREA}

Duarsnestled in the eastern Himalayan hills with sprawling terai, bhabar and mountain hills landscape between the Tista and Sankos rivers. The Tea industry in Duars is in deep crisis since the last couple of decades with the number of sick, abandoned, closed tea garden on the rise. Those still open are under tremendous financial crisis, due to equal contribution of globalization and the inability to compete in export markets. There have been numerous changes in garden ownership with new owners focusing on maximizing profits. The profit earned was further invested on diversification rather than towards the welfare of the tea industry. Every day brings in news of a new closure. Illness, destitution and deaths are being reported regularly. In recent years, tea garden labourers in Duars have suffered from serious starvation and hunger-related problems.

\section{OBJECTIVES}

The main objectives of the study are outlined below:

1. To know the tourist facility of the existing forest-based tourism

2. To identifies the tourist attitudes towards tea tourism

3.To know the reasons for showing interest to visit the tea garden in close future

\section{METHOD AND METHODOLOGY}

Primary data have been generated through questionnaire survey (2017) based on random sampling method. The questionnaire survey has been divided into three parts, parts-1 focus on demographic attributes of the tourist, part-2 focus on tourist's attitudes towards tea tourism and experienced about forest-based tourism and part-3 particularly highlight the tourist attitudes towards tea tourism and their willingness to visit in the future. The sample size is 155 respondents. Secondary data have been collected from different government and non-government sources.Thereafter, these data have been analysed and interpreted applying various statistical techniques.Current situation of the Duars tourism facility is measured by using five Point Likert-scales (1=very good, 2=Good, 3= Moderate, 4=Low and 5= Very low). The overall SWOT analysis and problem and prospect of tea tourism in Duars has been identified through the interaction with tourists, people involve in tourist business and teagarden labour.

\section{RESULT AND DISCUSSION}

The tea tourism that is moved by the history of the consumptive nature of tea. The tourists can get introduced himself with tea-garden, tea making process, the tea leaves plucking activity by women's labor et. (Jolliffe, 2007) Among the 155 respondents, 53\% male and $47 \%$ female which indicates that male and female, both are showing near 
about equal interest in travelling to this natural landscape of Duars. Most of the visitors are belonged to within state ( $57 \%$ ) , $29 \%$ tourist comes from other state of India and only $14 \%$ tourist comes from out of India. (Fig. 1 and Fig. 2)

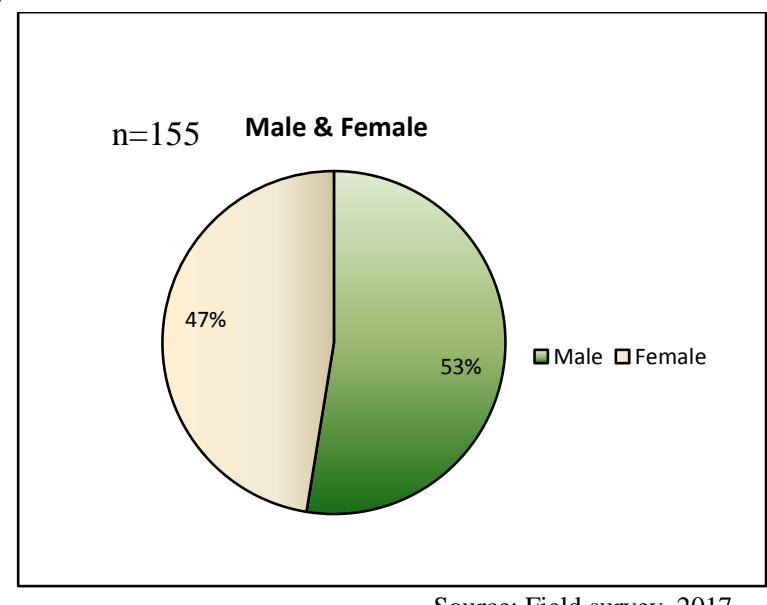

Fig. 1 Distribution of tourists

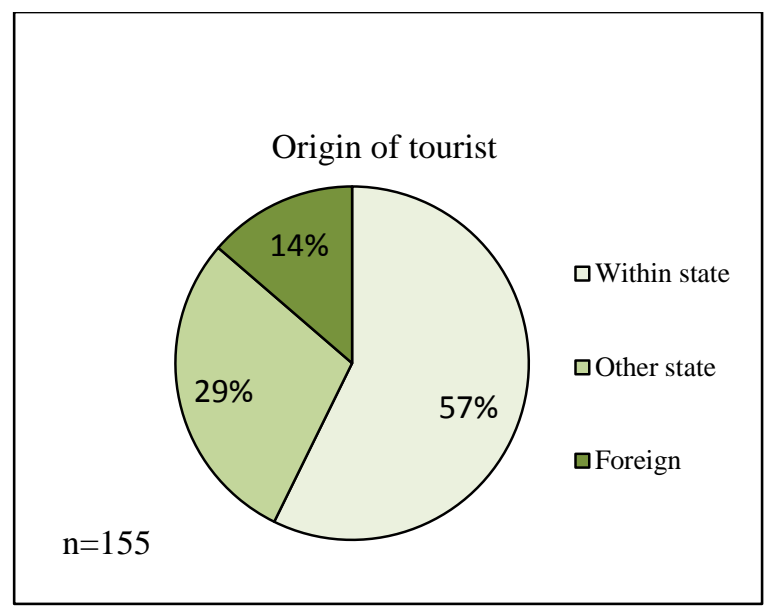

Fig. 2 Origin of tourist in Duars

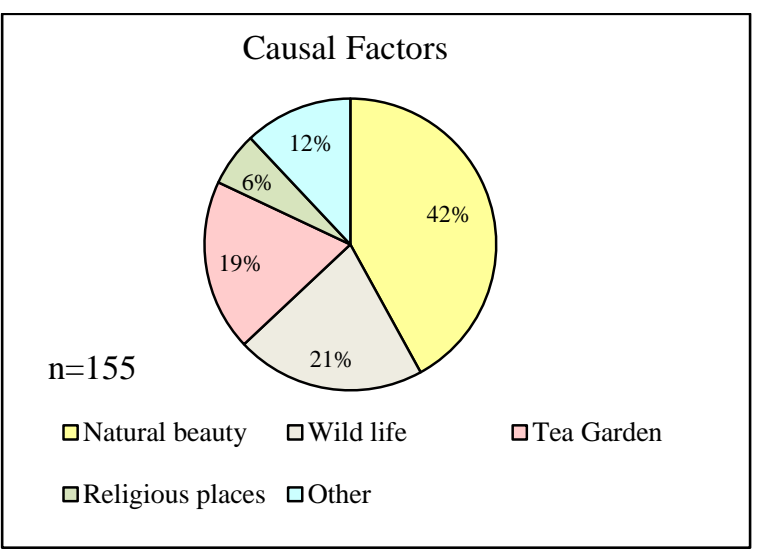

Source: Field survey, 2017

Fig: 3 Causal factors for selecting Duars as tourist destination by visitors

About Duars tourism, respondents are asked to select the most attractive pulling factor of tourist in this region, natural beauty $(42 \%)$ are identified by respondents, followed by wildlife $(21 \%)$, tea garden $(19 \%)$, religious places $(6 \%)$ and other cause $(12 \%)$ respectively.

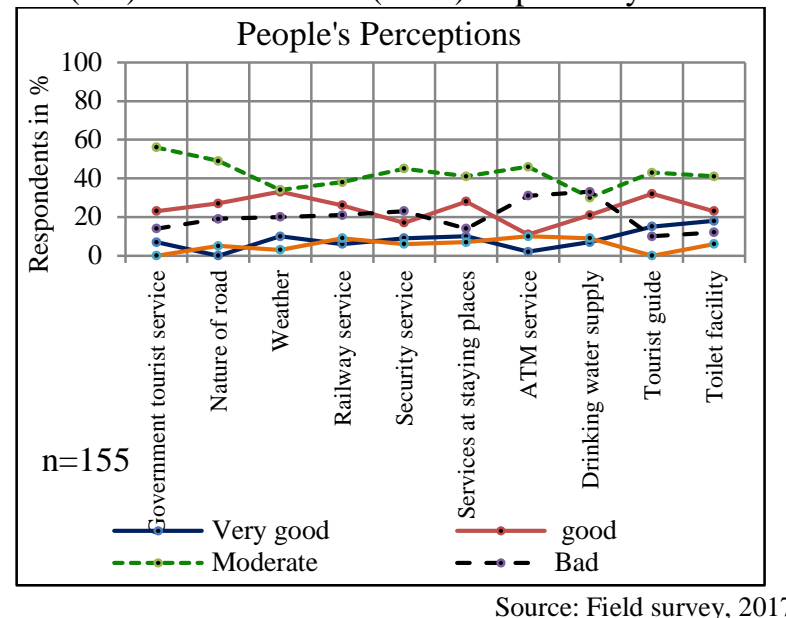

Fig. 4 People perception's about basic facilioties

Fig. 4 shows that basic tourist facility and tourist infrustructure is moderate quality. About basic tourust facilioties and tourist infrustructure, respondents are asked to highlight the factors that create problem in visiting to this region, government tourist service, security servuice, ATM service and tourist guide etc are identified by tourise and it comes under in likert scale 3 which indicate moderate quality. (Fig. 3 and Fig 4).

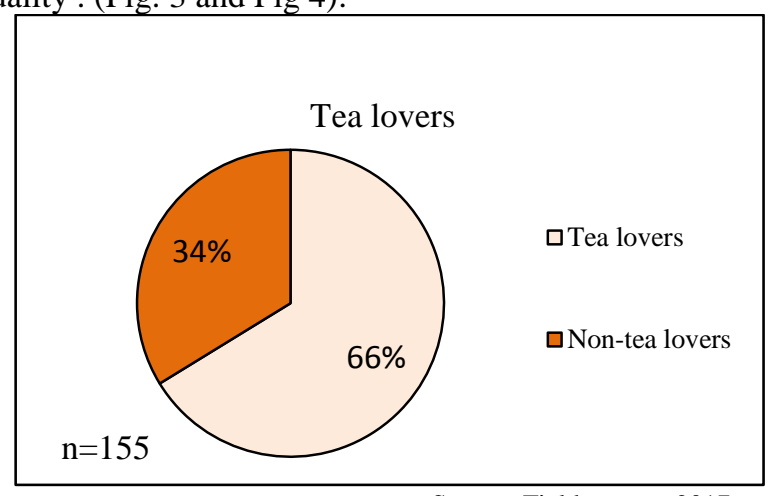

Source: Field survey, 2017

Fig. 5 Distribution of tea lovers and non-tea lovers

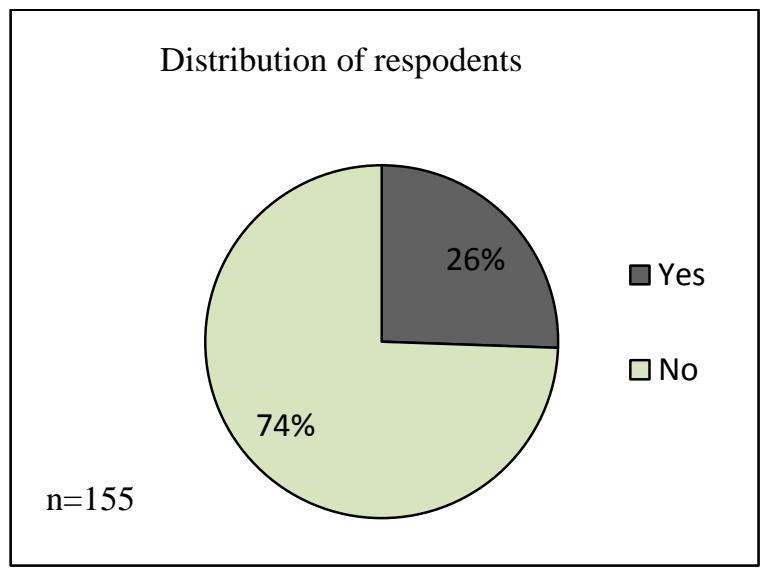

Source: Field survey, 2017

Fig. 6 Distribution of respondents on the basis of recent visit in tea garden 
The result shows that many respondents have interest in tea. Among 155, $66 \%$ respondents like tea which show popularity of tea among the tourist. Fig- 5 shows that only $34 \%$ respondents are non-tea lovers. The high \% of tea lover lead to development of tea tourism in Duars. Most of the tourist $(74 \%)$ recently visited in Duars show negetive interest in visiting the tea garden. Only $26 \%$ recently visit tourist in Duars show positive interest in visiting the tea garden at present.

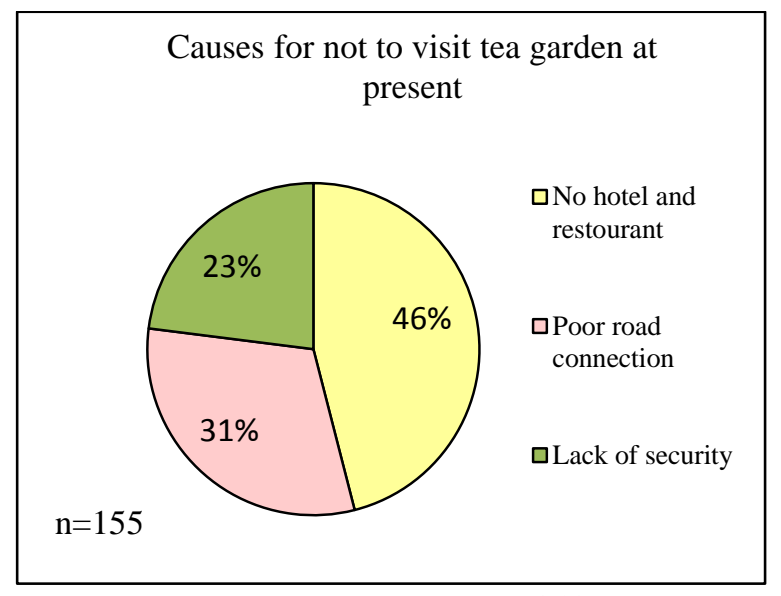

Source: Field survey, 2017

Fig. 7 Causal factors for not to visit the tea garden at present

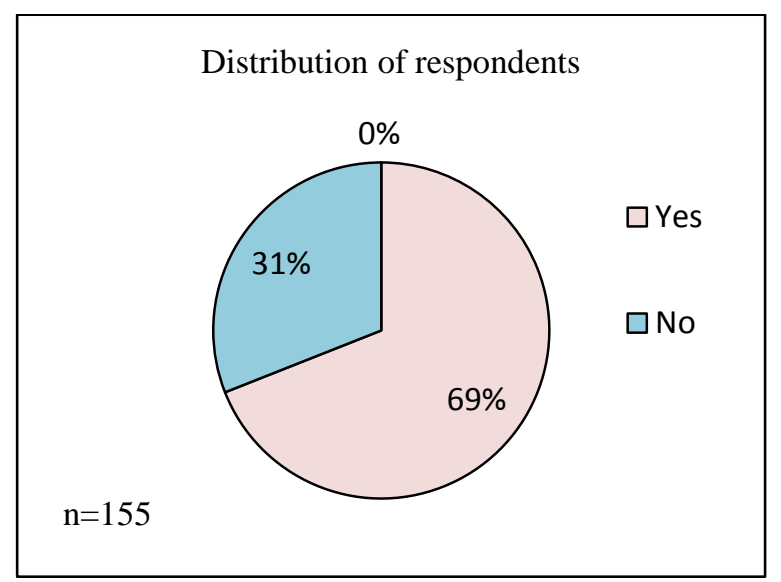

Source: Field survey, 2017

Fig. 8 Distribution of respondents on the basis of future visit to tea garden

About little interest (26\%) (Fig: 6) among the tourist to visit tea garden, the respondents are asked to choose the main causal factors for it, no hotel and restourents in tea garden campus is identified by $46 \%$ respondents followed by poor road connection (31\%) and lack of security (23\%) respectively. (Fig- 7) Positive attitudes have been found among the tourist from the study. $69 \%$ respondents show positive interest to visit tea garden in near future if basic facilities and tourist infrustructural facilities improved in this region. (Fig-8).

About tea tourism in Duars respondents are ask to select the most attractive tea tourism activity for the development of tea tourism in Duars landscape, watching tea leave plucking and also participate in it $(31 \%)$ is identified by most of the tourist, followed by know the tea making process $(17 \%)$, visit tea factory (12\%), enjoy with tea garden beauty (15\%), buy tea from tea factory and watching tea labour culture respectively. (Fig-9) Most of the respondents (about 30\%) give priority in transport facility development and tourist information center $(21 \%) .15 \%$ respondents give priority in participation of public companies should promote tea tourism along with government. (Fig- 10)

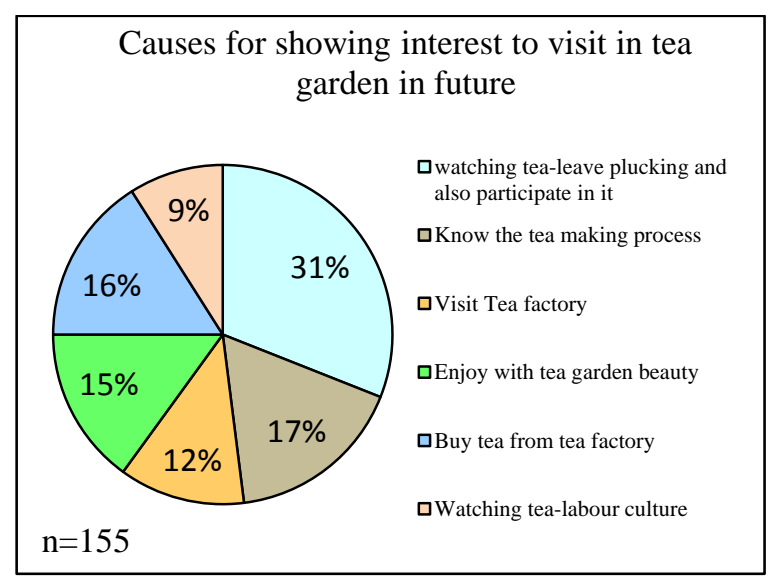

Fig: 9 Causes for showing interest to visit in tea garden in future

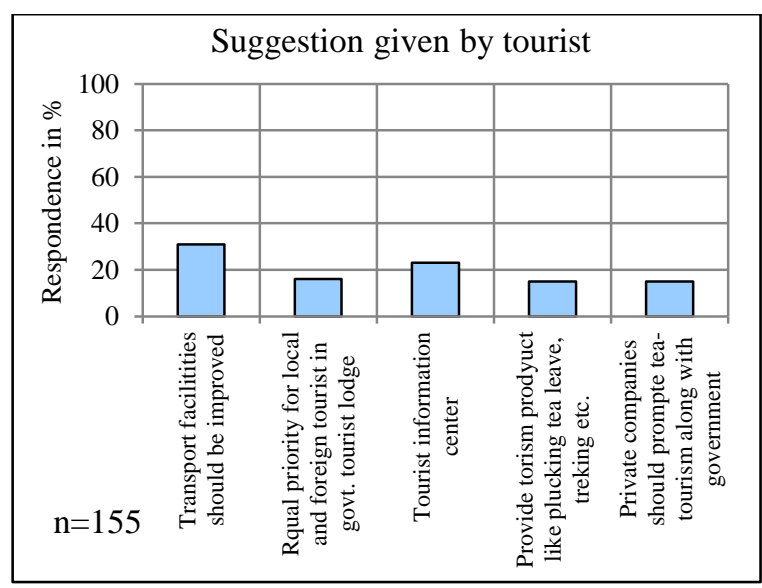

Fig. 10 Suggestion given by tourist for future develoment of tea tourism

\section{A. Strength}

\section{SWOT ANALYSIS}

1. Many tea gardenslie along the NH_31 which make accessible to distance tea garden with the development of feeder road that connect Teagarden and national highway.

2. Scope for watching wildlife as maximum tea garden share boundary with national park of Duars.

3. It is one of the best destinations of tourist where tourist can experience forest based tourism along with tea tourism.

\section{B. Weakness}

1. Absence of good communication network

2. Clean and hygienic food, accommodation. 
3. Lack of information about tourist

4. Lack of trained guard

\section{Opportunities}

1. Scope for tea tourism flourishes

2. Extra revenue generation

3. Improve economic conditions that in turn improve household income of the locals.

4. Wildlife management

\section{Threats}

1. Man-animal conflict mainly man-leopard conflict

2. The closed tea garden makes the tea labourer economically weaker.

\section{CONCLUSIONS}

The demographic profile of the tourist, problem face by local people, existing and expecting government support and environmental impacts of tea tourism are the important factors for development of tea tourism in Duars. Tea tourism helps to improve the socio-economic conditions of the local people by improving household income of the locals. Most of the tourists highlighted that they face problems while visit Duars such as poor quality road, poor ATM service, poor sanitation facility, poor drinking water etc. People involve in tourist business have highlighted that they also face some problem in Duars region.

A proper planning and designed are required for making tea-tourism more attractive and tourist destination center in
Duars along with existing forest based tourism. Local people should involve in the decision making process of tea tourism that make the tea tourism more strong and management friendly. Now government of West Bengal should take some initiative for development of tea tourism in Duars landscape such as:

1. Improve basic tourist infrastructure services

2. Develop tourist information center

3. Promote home stay in tea garden campus

4. Waste management system for making it environmentally sustainable

5. Social media involvement for the promotion of tea tourism

\section{REFERENCES}

[1] Boniface, P. (2003). Tasting tourism: travelling for food and drink, Ashgate Publishing, Aldershot, UK.

[2] Goowalla, H., \&Neog. D. (2011). Problem and Prospect of Tea Tourism in Assam- A SWOT Analysis, Tourists' Attitudes toward Tea Tourism, IPCSI, IACSIT Press, Singapore, 20:243-248

[3] Hall, C., Sharples, L., Mitchell, R., et al, (2003). Food tourism around the world: development, management and markets. Butterworth-Heinemann: Oxford.

[4] Jolliffe, L. (2007). Tea and Tourism: Tourists, Traditions and Transformations, Channel View Publications, Clevedon.

[5] Jolliffe,L., Mohamed, S.M., \& Aslam, M.S.M.(2009) 'Tea heritage tourism: evidence from Sri Lanka', Journal of Heritage Tourism,4 (4):331-344

[6] Chengwen, T., Kaizhong, Y., \&Zhaohui, P. (2001). Discussion on the Development of Ancient Culture Tourism Products--with Luoyang as an Example, Human Geography, 4.

[7] Zurong, XU,.(2007). Research on the Development of Hangzhou Tea Culture Tourism, Journal of Zhejiang Shuren University, 7. 